\title{
GEOSUD/SUDETEN NETWORK GPS DATA REPROCESSING AND HORIZONTAL SITE VELOCITY ESTIMATION
}

\author{
Jan KAPLON ${ }^{1)}$ *, Bernard KONTNY ${ }^{1)}$, Piotr GRZEMPOWSKI ${ }^{1)}$, \\ Vladimír SCHENK ${ }^{2)}$, Zdenka SCHENKOVÁ ${ }^{2)}$, Jan BALEK ${ }^{2)}$ and Jan HOLEŠOVSKÝ ${ }^{2)}$ \\ ${ }^{1)}$ Institute of Geodesy and Geoinformatics, Wrocław University of Environmental and Life Sciences, \\ Grunwaldzka 53, 50-357 Wroctaw, Poland \\ ${ }^{2)}$ Institute of Rock Structure and Mechanics, Academy of Sciences of the Czech Republic, v.v.i., \\ V Holešovičkách 41, 18209 Prague, Czech Republic \\ *Corresponding author's e-mail jan.kaplon@up.wroc.pl
}

\section{ARTICLE INFO}

Article history:

Received 14 May 2013

Accepted 5 November 2013

Available online 26 November 2013

\section{Keywords:}

Horizontal velocities of GPS sites Displacements

The Sudety Mts. area

\begin{abstract}
The geodynamic network of the Sudety Mts. (GEOSUD) was established in Poland in 1996. Simultaneously, the geodynamic network EAST SUDETEN was built on the Czech side in 1997 and, in 2001, it was extended for sites towards west (the WEST SUDETEN network). Since 1997 annual GPS campaign measurements have been performed on GEOSUD and EAST SUDETEN networks. Satellite observations were processed several times using the Bernese GPS Software, versions 4.0, 4.2 and 5.0. Different observation periods were processed applying different models for Earth's rotation, satellite ephemeris, pole motions, ocean loadings and antennas calibrations. This paper describes the result of uniform reprocessing of all measurements carried out in the period 1997-2012. The Bernese GPS Software V5.0 supported by the IGS Final product and absolute antenna phase centre model (IGS Final from 1409 GPS week (REPRO1 from 920 to 1408)) was used for the homogeneous reprocessing. The solution was referenced to the ITRF2008 datum using data from class A stations of the EUREF Permanent Network (EPN). The GEOSUD network was processed at IGG and the EAST and WEST SUDETEN networks at IRSM applying common processing strategy and the same reference EPN stations. Horizontal site velocities were estimated in a minimum constrained solution using ADDNEQ2 module of the Bernese GPS Software V5.0. The ITRF2008 a priori coordinates and velocities were introduced for fiducial stations belonging to EPN network. Estimated ITRF2008 velocities quality assessment was also performed by the comparison with reference EPN and ASG-EUPOS velocities. Final velocities were transformed to the ETRF2000(R08) applying the ITRF2008 plate-motion model. Paper summarizes the horizontal velocity estimations of the GEOSUD, EAST and WEST SUDETEN geodynamic network sites that cover the Sudety area and their tectonic foreland.
\end{abstract}

\section{INTRODUCTION}

Velocities of GNSS/GPS sites provide interesting information about long-term tectonic movements. The Sudety Mts. located between the Czech Republic and Poland and their close tectonic foreland are seismically and tectonically active areas of both countries. The area of Lower Silesia comprises three large tectonic units reactivated by young-alpine movements: the Sudety Mts., Fore-Sudetic Block and Fore-Sudetic Monocline, that are separated by the Sudetic Marginal Fault and the Odra River Fault Zone. Within crystalline rock blocks numerous fault zones, grabens and horsts were regenerated. The first historical earthquake was mentioned in the 10th century and other seismic events have been recorded till the present days. Their occurrence document tectonic movements in this area. They are also confirmed by hydrothermal activity, springs of mineral waters and, additionally, by geodetic data of 140 years long repeated levelling measurements (Kontny, 2003). Since the beginning of the nineties of the 20th century a geodetic research of existing Earth's crust movements has been conducted in these local areas.

In 1996, geodetic investigations using annual GPS campaigns started in the framework of the GEOSUD project (Cacoń and Dyjor, 1999). The network GEOSUD, covering initially the Polish Eastern Sudety and the Fore Sudetic areas, was extended to the entire region in 2000 (Kontny, 2003). In 1997, the EAST SUDETEN network (originally called SILESIA) was built for annual GPS campaigns on the Czech side of the Sudety Mts. (Schenk et al., 1999). Due to insufficient resolution of permanent GPS stations, repeated annual GPS campaigns have been performed (e.g. Kontny, 2003; Schenk et al., 1999, 2000, 2002, 2004a, 2004b; Bosy et. al., 2006). However, campaign observations give reliable results for site velocity estimations after a relatively long observation period (Schenk et al., 2010a). Establishing of permanent GNSS observations on the Polish and the Czech sides (Schenk et al., 2004b, $2010 \mathrm{~b})$ by the Institute of Geodesy and Geoinformatics (IGG) and by the Institute of Rock 


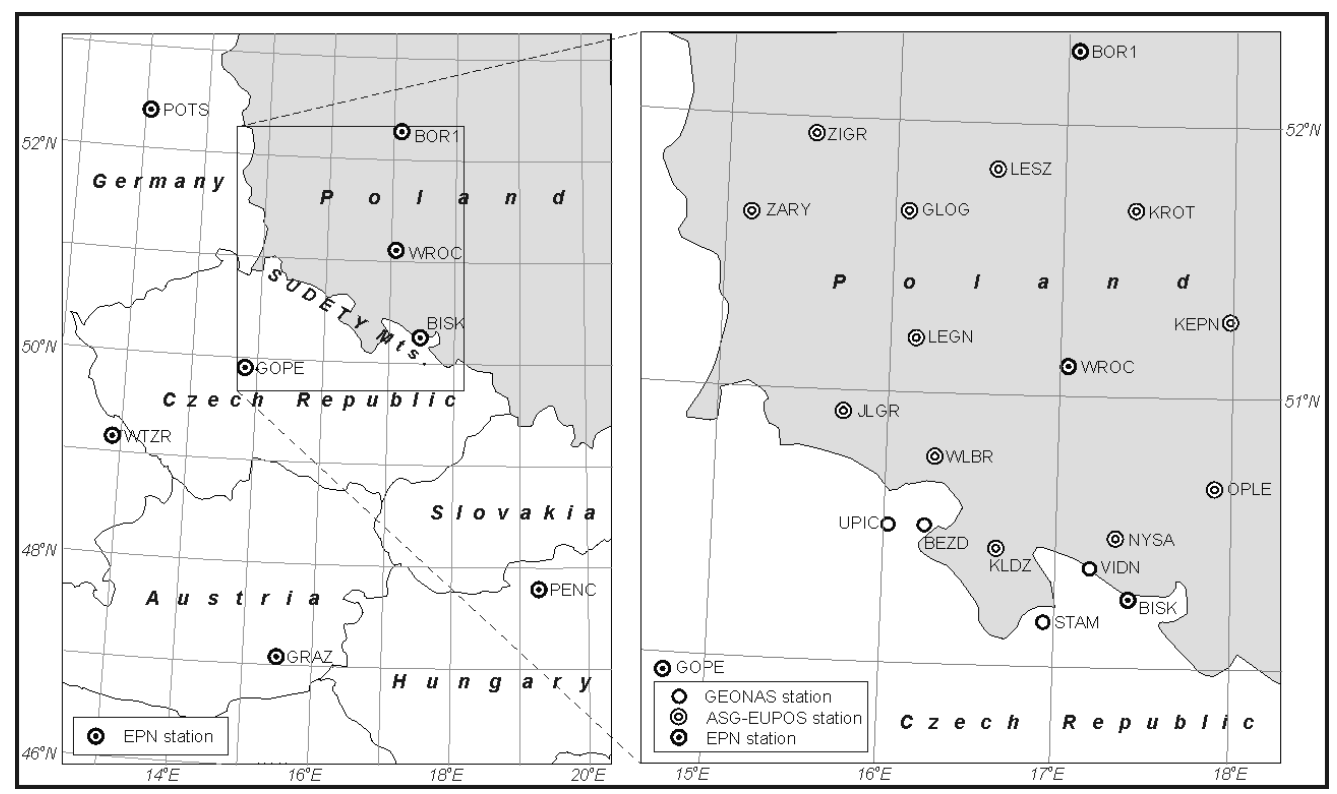

Fig. 1 Permanent GNSS stations used in reprocessing of GEOSUD and SUDETEN networks.

Structure and Mechanics (IRSM), allowed to process permanent and campaign data simultaneously. The Bernese GNSS software V5.0 (Dach et al., 2007) together with using new geophysical and antenna calibration models allowed reprocessing of all observed data in joint computation.

\section{OVERVIEW ON GEODYNAMIC STUDIES BASED ON GPS TECHNIQUE IN THE SUDETEN AND ADJACENT AREAS}

\subsection{GEOSUD NETWORK}

The GEOSUD (GEOdynamics of SUDetes) network covering the East Sudety Mts. and ForeSudetic Block was established in 1996. Selected sites from already existing research areas (Śnieżnik Massif, Paczków Graben and Stołowe Mts.) as well as new stations created this network (Cacoń et al., 1998; Cacoń and Dyjor, 1999) and are called below as "core" sites. These sites were located on crystalline rock outcrops with respect to geological and tectonic structures. Supplementary geodynamic "site profiles" located in the western part of the studied area completed the GEOSUD network in 2000.

Observation sessions of 48 hours were performed on the core sites of the network and 6 to 8 hours sessions on sites of the research profiles. Since 2000 the observations on all sites of the research profiles have been carried out in two repeated 12-hour sessions and two independent 24-hour sessions on the core sites of the network. Annual campaigns were performed till 2005. In 2006 and 2007, only several sites (BIEL, BRO1, KLOD, MECI, MNIS, RADO, SGOM, SNIE and ZLOT) were measured during two 24 hour sessions. During 2008 - 2010 period, KAGO, KLOD, SGOM, STOK, STRO, STOO, STRO, STRZ, TRZE sites were measured in two or more sessions of
24 hours to monitor the tectonic mobility of MiddleOdra Fault Zone (Grzempowski et al., 2012). In the beginning of 2008, the Ground Based Augmentation System network of permanent GNSS stations ASG-EUPOS (www.asgeupos.pl) was established. The following 12 stations of that system, GLOG, JLGR, KEPN, KLDZ, KROT, LEGN, LESZ, NYSA, OPLE, WLBR, ZARY and ZIGR, were included in the network processing (Grzempowski et al., 2012; Fig. 1).

The accuracy of the horizontal site velocities depends mainly on number and period of observations (Brockmann, 1996). From this viewpoint two additional campaigns have been carried out on the GEOSUD network sites in 2011 and 2012. The selection of sites for these measurements was done under the assumption that non-observed sites since 2005 or 2007 have to be measured. From that reason the following sites were observed: BARD, BIEL, BOBO, BOGA, BRO1, KAMI, KLOD, KOZO, LUBR, MNIS, PILA, PRZY, RADO, RATN, SLEZ, SOSN, SPAL, STOK, STOO, SZEL, SZYM, WILK, WINN and ZLOT. The BRAS, BRON and ULIC sites were destroyed before 2005 and BYCZ, JEDR, NIER, NYZ1, NYZ2, OTMU, RADZ sites have not been suitable for observations because of their bad state. These discontinued stations are not included in this paper.

The GPS observations from the 1997 - 2005 period were processed with the Bernese GPS software V4.2 (Hugentobler et al., 2001) according to the strategy designed for a local geodynamic network (Bosy and Kontny, 1998; Bosy et al., 2003; Schenk et al., 2002) and data from 1997 - 2010 period with the GPS Bernese V5.0 (Kapłon and Cacoń, 2009; Grzempowski et al., 2012). 


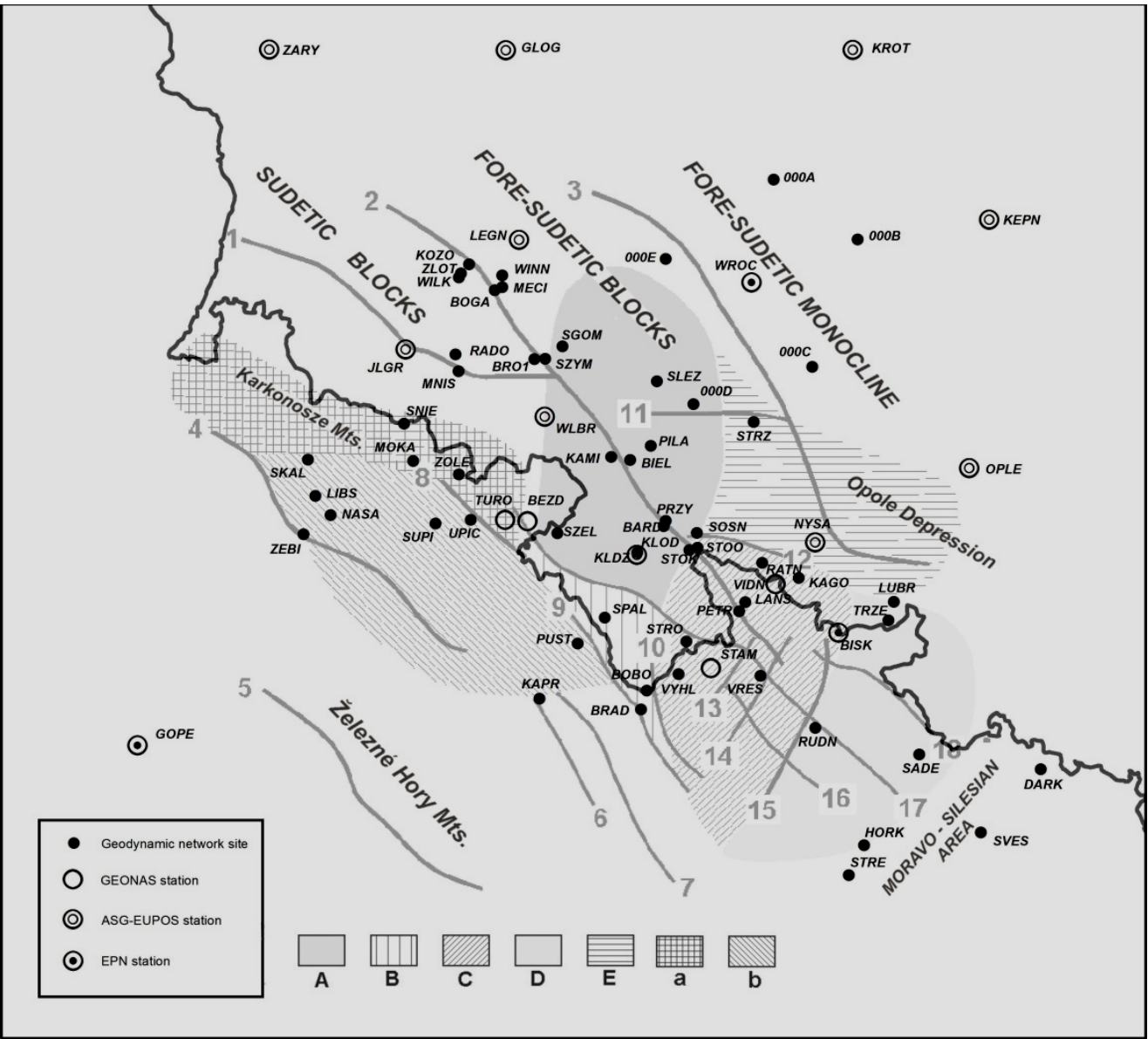

Fig. 2 GPS/GNSS stations used for reprocessing and their positions to structural areas and tectonic elements; 1 - Intrasudetic fault, 2 - Marginal Sudetic fault, 3 - Middle-Odra fault zone, 4 - Jílovice fault, 5 - Železné Hory fault zone, 6 - Semanín fault, 7 Kyšperk fault, 8 - Hronov-Poříćí fault, 9 - Králice fault, 10 - Bušín fault, 11 Strzelin fault, 12 - Žabkovice fault, 13 - Ramzová fault, 14 - Červenohorské sedlo fault, 15 - Štemberk-Horní Benešov fault, 16 - Klepáčov fault, 17 - Bělá fault, 18 Opavice shear zone; A - Lower-Sudeten terrain, B - Kladsko Furrow, C - Thrusting zone terrain, D - Moravo-Devonian terrain, E - Lower Silesian-Opole terrain; a - the Krkonoše Mts., b - Permian piedmont of the Krkonoše Mts.

\subsection{EAST AND WEST SUDETEN NETWORKS}

In the Czech territory the EAST SUDETEN network was established in 1997. The network was built to monitor recent activity of the NW-SE faults (the Main Sudetic, the Marginal Sudetic, the Bělá and Klepáčov faults, etc.) and movements along a few E$\mathrm{W}$ faults, e.g. the Opavice shear zone. Network site positions were selected after detailed geological, geophysical and geodetic analyses and consisted of 10 sites: BRAD, DARK, HORK, LANS, PETR, RUDN, SADE, SVES, STRE and VYHL. In 1997 the annual campaign for GEOSUD/EAST SUDETEN network was performed (Schenk et al., 2000, 2002). Later, the Czech network was extended for KAPR in 1999 and VRES in 2000. In 2001 the joint GEOSUD/EAST SUDETEN network was completed by two permanent GNSS stations BISK and SNEC belonging to the geodynamic network GEONAS (Schenk et al., 2010b).
GPS satellite signals were observed on all Czech sites annually always in 48-hour sessions at a sampling rate of 30 seconds and by this way they represent "core" sites of the network. Two solutions were performed: a constrained solution, where EPN stations (GOPE, BOR1, PENC and WTZR) were fiducial ones, and free local-network solution, where selected sites of the network had fixed positions. "Mean" annual velocities of the EAST SUDETEN network sites were assessed and with respect to their movement trends five dynamic terrains of the Sudetic structural blocks were depicted (Fig. 2): (A) Lower Sudeten terrain, (B) the Klodzko furrow, (C) Thrusting zone terrain, (D) Moravo-Devonian terrain and (E) Lower Silesian-Opole terrain (Schenk et al., 2002, 2003, 2004a). Reliability of site velocities monitored during 1997-2004 showed that convincing horizontal velocities for the north component can be obtained after 4 or 5 annual campaigns and, for the 


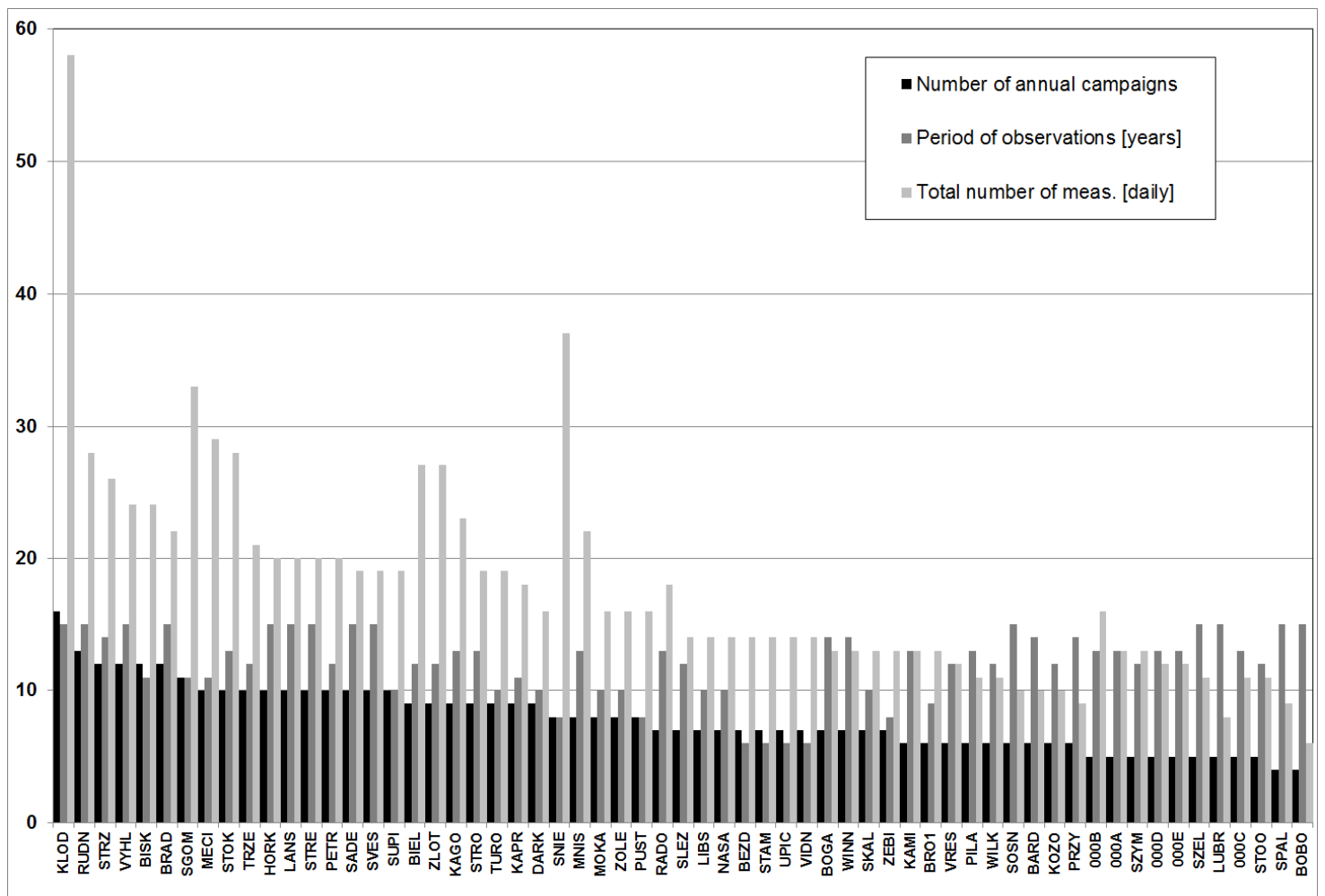

Fig. 3 Graph of: number of campaigns, period of observations [years] and total number of daily sessions.

east component, after 3 or 4 annual campaigns (Schenk et al., 2010a).

In 2001, the geodynamic network WEST SUDETEN was established (Schenk et al., 2006) to extend the observations to the west part of the Sudety Mts. The network sites (MOKA, ZOLE, TURO, SUPI, SKAL, LIBS, NASA and ZEBI) were situated in the Krkonoše Mts. and in their piedmont to monitor movements along the Hronov-Poŕíćí and Jílovice fault zones. The PUST site was placed in the Orlické hory Mts. opposite to the KAPR site to detect movements along the Kyšperk and the Semanín fault zones. In the period 2001-2005, five annual GPS campaigns on the GEOSUD, EAST and WEST SUDETEN networks were performed; since 2006 the campaigns have been organized on selected sites of the WEST and EAST SUDETEN networks.

The annual 2001-2005 GPS data of the WEST SUDETEN network were processed by the Bernese GPS software V5.0 (Dach et al., 2007) together with observations from BOR1, GRAZ, POTS and WTRZ stations taken as fiducial ones. Whole region displayed three areas with relatively different movement trends. The northern area, the Krkonoše Mts. structural block (a, Fig. 2), exhibited pronounce NW motion with respect to the central area that involves the Permian piedmont of the Krkonoše Mts (b, Fig. 2). In addition, evident dextral movement along the Železné hory Mts. fault zone was detected (Schenk et al., 2006).
Since 2001 the IRSM has built the GNSS GEOdynamic Network of the Academy of Sciences GEONAS (Schenk et al., 2004b, 2010b), http://geonas.irsm.cas.cz. Three permanent stations of this network (BISK, STAM, VIDN) lie inside the EAST SUDETEN network and further two (BEZD, UPIC) inside the WEST SUDETEN network. By this way the BEZD and UPIC stations are ready to detect activity along the Hronov-Poŕíćí fault zone and the STAM and VIDN stations activity around the Marginal Sudetic fault system.

\section{GPS DATA PROCESSING AND SITE VELOCITY ESTIMATION}

Reprocessing was performed on all available data files including only full daily sessions monitored on the Czech and the Polish networks. Altogether 166 sessions observed in the 1997 - 2012 period were processed by the Bernese GPS Software V5.0. Processing of daily sessions was done separately for the Czech and for the Polish sites by IRSM and IGG respectively. Both parties used the same parameters and physical models (Table 1) as well as processing strategy. The main advantage of the presented solution to the earlier research in local kinematics of tectonic structures of the Sudety Mts. area (Kontny, 2003; Bosy et al., 2006; Kapłon and Cacoń, 2009; Schenk et al., 2002, 2003, 2004a, 2006, 2010a, 2010b) is the homogeneous processing of the data for the longest available period of observations. 
Table 1 Models and parameters used for recalculation of GEOSUD/SUDETEN network daily sessions.

\begin{tabular}{ll}
\hline PARAMETR & MODEL \\
\hline Satellite orbits and Earth rotation parameters & IGS Final from 1409 GPS week (REPRO1 since 920 to 1408) \\
Ionosphere model & CODE Final \\
Ocean loadings & FES2004 \\
Planetary ephemeris & DE200 \\
Nutation model & IAU2000 \\
Polar motion model & IERS2000 \\
GPS antenna phase center variation model & Absolute parameters converted from ANTEX: igs08.atx \\
Elevation cut-off angle during the processing & $10^{0}$ \\
Observation elevation weighting method & $1 /($ cos(z), where z is the zenith angle \\
A-priori troposphere model & Saastamoinen with Dry Niell mapping function \\
Estimated troposphere model & Saastamoinen with Wet Niell mapping function (site specific) \\
\hline
\end{tabular}

\subsection{PROCESSING STRATEGY}

The reprocessing procedure had started in November 2011 and was finished in November 2012. Calculation was automated by using common Bernese software process control file (PCF). Taking into account the size of processed networks and length of sessions (24h in most cases) the L5/L3 strategy was chosen, following the better ambiguity resolution ratio than in standard Bernese QIF (Quasi Iono-Free) strategy described by Schenk et al. (2010a). The processing scheme contains the following steps:

(a) Copying and downloading of necessary files.

(b) Preparing satellite orbits and clocks and pole motions data.

(c) Conversion from RINEX to internal Bernese, screening of GPS code data and synchronization with satellite clocks.

(d) Forming of GPS baselines using MAXOBS strategy (Dach et al., 2007) with forced network skeleton, GPS phase data screening.

(e) „Ambiguity float“ solution of network, calculation of wide-lane (L5) phase ambiguities, calculation of narrow-lane (L3) phase ambiguities - both using SIGMA ambiguity resolution method (Dach et al., 2007).

(f) Computation of ,ambiguity fixed" solution using L1 and L2 ambiguities resolved during ,narrowlane" step.

(g) Final solution of session using minimum constrain condition on EPN class A stations coordinates coming from weekly combined solutions (REPRO1 for weeks 920-1408 and final routine after week 1408) and saving normal equation file.

The datum for each session was realized by selecting seven EPN class A stations - BOR1, GOPE,
GRAZ, PENC, POTS, WROC, WTZR (Fig. 1). Six of these stations (without GRAZ) were also used as EPN fiducial stations for the IGS08 datum realization. GRAZ station was chosen additionally, because of its location and availability of data that support a minimum constrained solution of each session using 3 reference stations at least. The reference stations provide the basis for later sessions stacking into a single velocity solution, because no other common sites were processed by IRSM and IGG.

\subsection{ITRF2008 VELOCITY ESTIMATION AND QUALITY ASSESSMENT}

The Bernese normal equation files and ITRF2008 a priori coordinates and velocities of reference stations were used to calculate the GEOSUD/SUDETEN site velocities. The calculation was done at IRSM using ADDNEQ2 module of the Bernese GPS Software V5.0. This module performs the least-squares solution of stacked system of normal equations (Dach et al., 2007) from all sessions. Weighting of particular sessions was made only according to the quality of the daily session solutions stored in normal equation files - and no external weighting parameters were introduced. The velocity estimation was performed applying minimum constraint condition on a priori ITRF2008 coordinates and velocities of EPN class A stations (BOR1, GOPE, GRAZ, PENC, POTS, WROC, WTZR). The solution additionally includes EPN BISK station and Polish ASG-EUPOS network permanent stations (GLOG, JLGR, KLDZ, KROT, LEGN, LESZ, NYSA, OPLE, WLBR, ZARY, ZIGR) (Table 2) covering the Polish part of Sudety Mts. and their foreland as ordinary GPS observation points. (Figs 1,2). Introduction of these additional permanent sites (control sites) will allow checking the consistency of the solution, because of their known coordinates and velocities. 
Table 2 ITRF2008 coordinates (epoch 2005.0) and velocities of reference and control stations.

\begin{tabular}{|c|c|c|c|c|c|c|}
\hline Site & $\mathbf{X}$ & $\begin{array}{c}\mathbf{Y} \\
{[\mathbf{m}]}\end{array}$ & $\mathbf{Z}$ & $\mathbf{v X}$ & $\begin{array}{c}\mathbf{v Y} \\
\text { [m/year] }\end{array}$ & $\mathbf{v Z}$ \\
\hline \multicolumn{7}{|c|}{ Reference sites for minimum constrained solution } \\
\hline BOR1 & 3738358.4558 & 1148173.7126 & 5021815.7776 & -0.0172 & 0.0155 & 0.0088 \\
\hline GOPE & 3979316.1290 & 1050312.4787 & 4857067.1105 & -0.0158 & 0.0166 & 0.0103 \\
\hline GRAZ & 4194423.8186 & 1162702.6904 & 4647245.4117 & -0.0165 & 0.0179 & 0.0110 \\
\hline PENC & 4052449.4813 & 1417681.1227 & 4701407.1205 & -0.0179 & 0.0173 & 0.0095 \\
\hline POTS & 3800689.6389 & 882077.3888 & 5028791.3316 & -0.0161 & 0.0158 & 0.0091 \\
\hline WROC & 3835751.3061 & 1177249.9647 & 4941605.2550 & -0.0167 & 0.0160 & 0.0096 \\
\hline WTZR & 4075580.5555 & 931853.7999 & 4801568.1391 & -0.0158 & 0.0172 & 0.0104 \\
\hline \multicolumn{7}{|c|}{ Control stations } \\
\hline BISK & 3898945.9442 & 1223993.3617 & 4881826.4472 & -0.0166 & 0.0164 & 0.0097 \\
\hline GLOG & 3809340.6799 & 1097657.8740 & 4979900.9035 & -0.0172 & 0.0160 & 0.0087 \\
\hline JLGR & 3878289.4318 & 1092567.0683 & 4928218.0485 & -0.0169 & 0.0158 & 0.0097 \\
\hline KLDZ & 3900141.6385 & 1166529.8547 & 4894068.5355 & -0.0166 & 0.0165 & 0.0096 \\
\hline KROT & 3779936.4261 & 1187254.5245 & 4981792.5588 & -0.0169 & 0.0160 & 0.0086 \\
\hline LEGN & 3846687.4424 & 1114288.5483 & 4947658.8229 & -0.0166 & 0.0164 & 0.0098 \\
\hline LESZ & 3784869.6012 & 1126771.5547 & 4991968.1454 & -0.0175 & 0.0157 & 0.0086 \\
\hline NYSA & 3882469.5217 & 1211763.0758 & 4896966.4315 & -0.0168 & 0.0162 & 0.0101 \\
\hline OPLE & 3854337.7791 & 1246354.4185 & 4910366.5040 & -0.0170 & 0.0162 & 0.0092 \\
\hline WLBR & 3880292.0269 & 1133212.0745 & 4917654.7221 & -0.0152 & 0.0171 & 0.0119 \\
\hline ZARY & 3828791.4612 & 1036393.5599 & 4978198.4853 & -0.0166 & 0.0160 & 0.0092 \\
\hline ZIGR & 3796759.7738 & 1053954.9912 & 4998889.6011 & -0.0171 & 0.0157 & 0.0089 \\
\hline
\end{tabular}

Coordinates and velocities of ASG-EUPOS stations were provided to the authors by the courtesy of Military University of Technology in Warsaw, Poland. The coordinates and velocities are the result of cumulative 2008-2012 minimum constraint solution on coordinates and velocities published for 1680 GPS week by EPN in EPN_A_IGS08_C1680.SSC file. This set of coordinates and velocities was expressed in ETRF2000(R08) for the epoch 2011.0 and it was recalculated by the authors to ITRF2008 (epoch 2005.0) using methodology presented by Boucher and Altamimi (2011). For the comparison, the coordinates of EPN A class stations expressed in ETRF2000(R08) and published in EPN A ETRF2000 C1680.SNX (epoch 2005.0) file were re-calculated to ITRF2008 (epoch 2005.0) using the same strategy. The complete set of coordinates and velocities of reference and control stations are presented in Table 2.

The outlier rejection was performed for all residuals from the combination process that exceed 15 $\mathrm{mm}$ for the horizontal coordinate components and 20 $\mathrm{mm}$ for the vertical component. Totally 34 outliers for different sites were removed (3 for horizontal and vertical components and 31 for vertical components). None site had been removed from the solutions according to the outlier rejection.

To verify the reliability of the velocity estimation, final velocities of EPN class A stations and ASG-EUPOS stations were compared with their a priori values (Fig. 4) in North, East and Up (NEU) directions. These comparisons expressed the quality of the solution. The results of the comparison reveal a good compatibility of horizontal coordinates $(\mathrm{dN}$, $\mathrm{dE})$ and velocities (dVN, dVE). The average discrepancy of coordinates for all processed EPN class
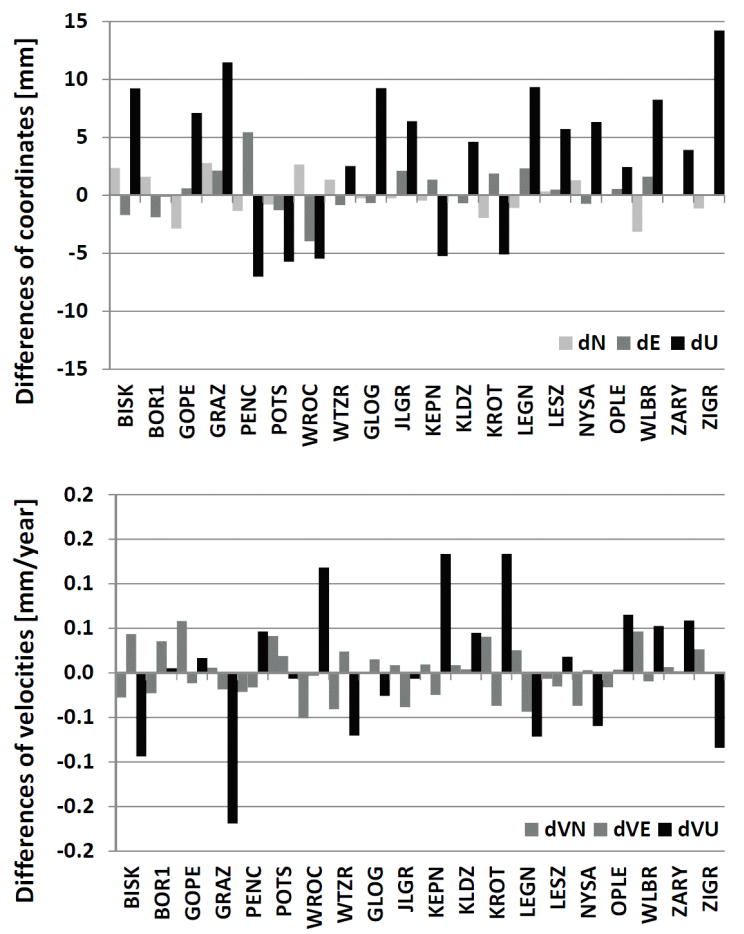

Fig. 4 Comparison of ITRF2008 reference coordinates (epoch 2005.0) and velocities with estimated values for EPN class A and ASG-EUPOS stations in NEU directions. 


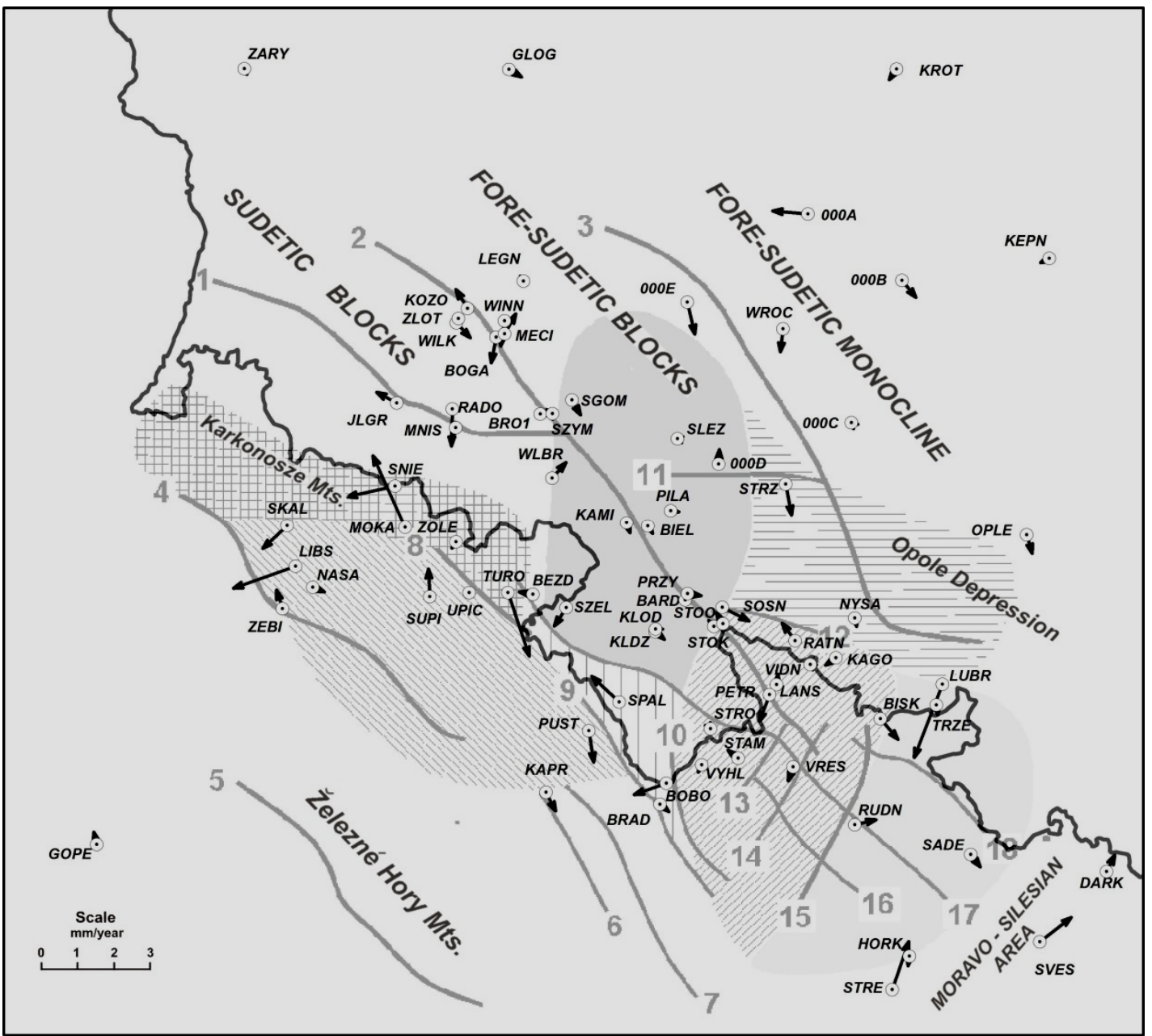

Fig. 5 Vectors of horizontal intraplate velocities (ITRF2008 reduced with ITRF2008 plate-motion model).

A and ASG-EUPOS stations is equal to 0.0, 0.3, $3.6 \mathrm{~mm}$ for North, East and Up components with 1.6, 2.0, $7.2 \mathrm{~mm}$ of RMS errors, respectively. Average discrepancy of velocities is equal to $0.0,0.0$, $0.1 \mathrm{~mm} /$ year for North, East and Up components with $0.3,0.2,0.8 \mathrm{~mm} /$ year of RMS error. Horizontal velocities are presented in this paper only, because the solution was made primarily for the geodynamic research. The consistency of estimated vertical velocities with respect to the reference values (dVU RMS error of $0.8 \mathrm{~mm} /$ year) and the number of vertical outliers also indicates that for the analysis of vertical movements the different processing approach should be used e.g. using more advanced troposphere modelling. The average coordinate repeatability obtained during the velocity estimation is $2.1 \mathrm{~mm}$ for horizontal and $8.0 \mathrm{~mm}$ for vertical components.

\section{INTRAPLATE VELOCITY ESTIMATION}

To calculate the intraplate velocities the absolute plate-motion model ITRF2008 have been used (Altamimi et al., 2012). The model has been chosen in accordance with a coordinate system in which the calculation of velocity was performed. Values for rates of the Eurasian plate-motion defined by angular velocities $\omega_{\mathrm{x}}, \omega_{\mathrm{y}}$ and $\omega_{\mathrm{z}}$ are respectively $-0.083,-0.534$ and 0.750 mas/year. Resulting intraplate velocities are presented in Table 3 and Figure 5.

The estimated intraplate velocities may be validated by the comparison with the results published by EPN and ASG-EUPOS. Both these organizations publish their intraplate velocities in ETRF2000(R08) datum, thus small bias is expected between intraplate velocities computed using ITRF2008 plate-motion model and those estimated directly in ETRF2000(R08). Validation was performed on all processed EPN class A and ASG-EUPOS stations, and is presented in Figure 6. The comparison was done between estimated intraplate velocities and EPN/ASG-EUPOS ETRF2008(R08) results for 1680 GPS week. Obtained velocity differences in North and East directions $(\mathrm{dvN}, \mathrm{dvE})$ revealed average biases of -0.04 for North and $0.41 \mathrm{~mm} /$ year for East component, with 0.31 and $0.24 \mathrm{~mm} /$ year RMS errors, respectively. These biases may be explained by the differences between ITRF2008 Eurasian plate-motion model annual rates presented above and ITRF2008 to ETRF2000 transformation parameters annual rates 
Table 3 Estimated ITRF2008 coordinates (epoch 2005.0), velocities and horizontal intraplate velocities of processed sites.

\begin{tabular}{|c|c|c|c|c|c|c|c|c|c|c|}
\hline \multirow{3}{*}{ Site } & \multicolumn{3}{|c|}{ Coordinates [m] } & \multicolumn{5}{|c|}{ Velocities } & \multirow{2}{*}{\multicolumn{2}{|c|}{$\begin{array}{c}\begin{array}{c}\text { RMS of } \\
\text { velocity } \\
\text { components }\end{array} \\
\text { [mm/year] }\end{array}$}} \\
\hline & \multirow{2}{*}{$\mathbf{X}$} & \multirow{2}{*}{$\mathbf{Y}$} & \multirow{2}{*}{$\mathbf{Z}$} & \multicolumn{3}{|c|}{ ITRF2008 [m/year] } & \multicolumn{2}{|c|}{$\begin{array}{l}\text { Intraplate } \\
\text { [mm/year] }\end{array}$} & & \\
\hline & & & & $\mathbf{v X}$ & vY & $\mathrm{vZ}$ & $\mathbf{v N}$ & $\mathbf{v E}$ & $\mathbf{v N}$ & $\mathbf{v E}$ \\
\hline \multicolumn{11}{|c|}{ GEOSUD network } \\
\hline BARD & 3892177.3160 & 1171518.2150 & 4899129.8472 & -0.0165 & 0.0162 & 0.0100 & -0.1 & -0.1 & 0.1 & 0.1 \\
\hline BIEL & 3881767.0957 & 1158317.1126 & 4910586.4965 & -0.0147 & 0.0169 & 0.0121 & -0.2 & 0.1 & 0.1 & 0.1 \\
\hline ВОВО & 3926489.3125 & 1178447.7308 & 4870551.2300 & -0.0153 & 0.0157 & 0.0108 & -0.3 & -1.0 & 0.1 & 0.1 \\
\hline BOGA & 3858959.9389 & 1111469.8406 & 4938955.2350 & -0.0160 & 0.0161 & 0.0093 & -0.8 & -0.2 & 0.1 & 0.1 \\
\hline BRO1 & 3869587.1552 & 1126508.1802 & 4927403.9069 & -0.0178 & 0.0157 & 0.0083 & 0.0 & -0.1 & 0.1 & 0.1 \\
\hline KAGO & 3891096.4577 & 1209942.1742 & 4890789.8859 & -0.0173 & 0.0157 & 0.0088 & -0.2 & -0.3 & 0.1 & 0.1 \\
\hline KAMI & 3882836.9271 & 1153186.3452 & 4911057.8718 & -0.0159 & 0.0165 & 0.0104 & -0.3 & 0.1 & 0.1 & 0.1 \\
\hline KLOD & 3899677.3320 & 1166448.3886 & 4894517.4661 & -0.0168 & 0.0161 & 0.0098 & 0.0 & -0.1 & 0.1 & 0.1 \\
\hline $\mathrm{KOZO}$ & 3855849.7477 & 1103041.3709 & 4943134.3975 & -0.0173 & 0.0155 & 0.0097 & 0.6 & -0.4 & 0.1 & 0.1 \\
\hline LUBR & 3887604.9117 & 1236062.2225 & 4886926.1996 & -0.0159 & 0.0156 & 0.0073 & -2.2 & -0.9 & 0.1 & 0.1 \\
\hline MECI & 3857717.6558 & 1113173.7910 & 4939500.6440 & -0.0157 & 0.0167 & 0.0121 & 0.6 & 0.3 & 0.1 & 0.1 \\
\hline MNIS & 3878404.7247 & 1107735.6130 & 4924909.7131 & -0.0149 & 0.0165 & 0.0115 & -0.3 & -0.1 & 0.1 & 0.1 \\
\hline PILA & 3877157.2735 & 1162597.0818 & 4913059.9221 & -0.0164 & 0.0165 & 0.0103 & 0.0 & 0.3 & 0.1 & 0.1 \\
\hline PRZY & 3890898.5452 & 1171671.1841 & 4900099.5206 & -0.0181 & 0.0162 & 0.0082 & -0.1 & 0.4 & 0.1 & 0.1 \\
\hline RADO & 3875336.0721 & 1105817.4447 & 4927826.1939 & -0.0152 & 0.0165 & 0.0098 & -1.1 & 0.0 & 0.1 & 0.1 \\
\hline RATN & 3891105.1432 & 1199396.8052 & 4893202.7753 & -0.0167 & 0.0158 & 0.0107 & 0.5 & -0.4 & 0.1 & 0.1 \\
\hline SGOM & 3864595.4578 & 1132907.9892 & 4929708.7980 & -0.0179 & 0.0160 & 0.0076 & -0.5 & 0.3 & 0.1 & 0.1 \\
\hline SLEZ & 3863953.0812 & 1159788.1555 & 4924611.7328 & -0.0166 & 0.0160 & 0.0100 & 0.0 & -0.1 & 0.1 & 0.1 \\
\hline SNIE & 3894102.9319 & 1097525.2915 & 4916316.9376 & -0.0161 & 0.0148 & 0.0094 & -0.3 & -1.5 & 0.1 & 0.1 \\
\hline SOSN & 3890702.4679 & 1180561.1738 & 4898142.1649 & -0.0185 & 0.0165 & 0.0073 & -0.4 & 0.8 & 0.1 & 0.1 \\
\hline SPAL & 3915700.9623 & 1162632.7294 & 4883269.6940 & -0.0183 & 0.0149 & 0.0088 & 0.8 & -0.8 & 0.1 & 0.1 \\
\hline STOK & 3894788.7733 & 1179751.8689 & 4895231.1877 & -0.0162 & 0.0162 & 0.0108 & 0.2 & -0.2 & 0.1 & 0.1 \\
\hline STOO & 3893644.3507 & 1181694.7614 & 4895603.1185 & -0.0190 & 0.0153 & 0.0075 & 0.3 & -0.2 & 0.1 & 0.1 \\
\hline STRO & 3913803.8240 & 1185439.7141 & 4879805.1898 & -0.0168 & 0.0163 & 0.0097 & -0.1 & 0.1 & 0.1 & 0.1 \\
\hline STRZ & 3863630.4497 & 1187507.5085 & 4917632.8300 & -0.0161 & 0.0165 & 0.0093 & -1.0 & 0.2 & 0.1 & 0.1 \\
\hline SZEL & 3902871.3357 & 1144611.9025 & 4897809.8254 & -0.0171 & 0.0157 & 0.0083 & -0.6 & -0.4 & 0.1 & 0.1 \\
\hline SZYM & 3868552.8724 & 1129262.3142 & 4927464.1629 & -0.0163 & 0.0163 & 0.0105 & 0.1 & 0.1 & 0.1 & 0.1 \\
\hline TRZE & 3891810.1867 & 1236000.7961 & 4883665.5018 & -0.0173 & 0.0161 & 0.0089 & -0.3 & 0.0 & 0.1 & 0.1 \\
\hline WILK & 3859360.6833 & 1101374.1650 & 4940925.7289 & -0.0163 & 0.0166 & 0.0096 & -0.5 & 0.4 & 0.1 & 0.1 \\
\hline WINN & 3855309.4680 & 1112359.0697 & 4941442.1449 & -0.0154 & 0.0163 & 0.0101 & -0.8 & -0.1 & 0.1 & 0.1 \\
\hline ZLOT & 3858430.7219 & 1101555.6052 & 4941627.7808 & -0.0165 & 0.0159 & 0.0096 & -0.2 & -0.2 & 0.1 & 0.1 \\
\hline \multicolumn{11}{|c|}{ Wroclaw leveling network } \\
\hline 000A & 3813044.9695 & 1175837.5374 & 4959327.9564 & -0.0166 & 0.0149 & 0.0098 & 0.1 & -1.1 & 0.1 & 0.1 \\
\hline $000 \mathrm{~B}$ & 3817956.6401 & 1201699.1181 & 4949466.9681 & -0.0166 & 0.0165 & 0.0095 & -0.5 & 0.4 & 0.1 & 0.1 \\
\hline $000 \mathrm{C}$ & 3847468.8823 & 1198864.6839 & 4927374.5166 & -0.0174 & 0.0158 & 0.0092 & 0.1 & -0.1 & 0.1 & 0.1 \\
\hline 000D & 3865113.4140 & 1170747.8520 & 4920418.3574 & -0.0172 & 0.0160 & 0.0100 & 0.5 & 0.0 & 0.1 & 0.1 \\
\hline $000 \mathrm{E}$ & 3838224.1538 & 1153513.9080 & 4945260.5133 & -0.0126 & 0.0175 & 0.0137 & -1.0 & 0.2 & 0.1 & 0.1 \\
\hline \multicolumn{11}{|c|}{ ASG-EUPOS stations } \\
\hline GLOG & 3809340.6858 & 1097657.8750 & 4979900.9106 & -0.0174 & 0.0161 & 0.0085 & -0.2 & 0.4 & 0.1 & 0.1 \\
\hline JLGR & 3878289.4353 & 1092567.0715 & 4928218.0533 & -0.0169 & 0.0154 & 0.0097 & 0.3 & -0.6 & 0.1 & 0.1 \\
\hline KEPN & 3802580.5757 & 1234329.1558 & 4953272.3337 & -0.0168 & 0.0157 & 0.0097 & -0.1 & -0.3 & 0.1 & 0.1 \\
\hline KLDZ & 3900141.6416 & 1166529.8549 & 4894068.5390 & -0.0164 & 0.0166 & 0.0100 & -0.2 & 0.3 & 0.1 & 0.1 \\
\hline KROT & 3779936.4240 & 1187254.5258 & 4981792.5536 & -0.0163 & 0.0158 & 0.0099 & -0.3 & -0.2 & 0.1 & 0.1 \\
\hline LEGN & 3846687.4482 & 1114288.5524 & 4947658.8295 & -0.0171 & 0.0158 & 0.0094 & 0.2 & -0.1 & 0.1 & 0.1 \\
\hline LESZ & 3784869.6042 & 1126771.5561 & 4991968.1501 & -0.0173 & 0.0156 & 0.0087 & -0.2 & -0.1 & 0.1 & 0.1 \\
\hline NYSA & 3882469.5248 & 1211763.0760 & 4896966.4372 & -0.0169 & 0.0162 & 0.0094 & -0.3 & 0.1 & 0.1 & 0.1 \\
\hline OPLE & 3854337.7804 & 1246354.4195 & 4910366.5059 & -0.0165 & 0.0164 & 0.0096 & -0.6 & 0.2 & 0.1 & 0.1 \\
\hline WLBR & 3880292.0338 & 1133212.0782 & 4917654.7265 & -0.0152 & 0.0170 & 0.0126 & 0.5 & 0.4 & 0.1 & 0.1 \\
\hline ZARY & 3828791.4635 & 1036393.5605 & 4978198.4884 & -0.0163 & 0.0161 & 0.0097 & -0.2 & 0.1 & 0.1 & 0.1 \\
\hline ZIGR & 3796759.7831 & 1053954.9938 & 4998889.6116 & -0.0178 & 0.0155 & 0.0084 & 0.2 & 0.0 & 0.1 & 0.1 \\
\hline & & & EPN cla: & A station & & & & & & \\
\hline BISK & 3898945.9486 & 1223993.3613 & 4881826.4558 & -0.0171 & 0.0167 & 0.0088 & -0.6 & 0.5 & 0.1 & 0.1 \\
\hline BOR1 & 3738358.4551 & 1148173.7104 & 5021815.7785 & -0.0171 & 0.0159 & 0.0087 & -0.4 & 0.3 & 0.1 & 0.1 \\
\hline GOPE & 3979316.1354 & 1050312.4810 & 4857067.1141 & -0.0161 & 0.0164 & 0.0108 & 0.4 & -0.1 & 0.1 & 0.1 \\
\hline GRAZ & 4194423.8236 & 1162702.6940 & 4647245.4220 & -0.0176 & 0.0174 & 0.0098 & 0.5 & 0.6 & 0.1 & 0.1 \\
\hline PENC & 4052449.4760 & 1417681.1266 & 4701407.1144 & -0.0174 & 0.0173 & 0.0097 & -0.3 & 0.7 & 0.1 & 0.1 \\
\hline POTS & 3800689.6364 & 882077.3869 & 5028791.3266 & -0.0165 & 0.0159 & 0.0093 & 0.1 & 0.1 & 0.1 & 0.1 \\
\hline WROC & 3835751.3020 & 1177249.9593 & 4941605.2524 & -0.0156 & 0.0163 & 0.0102 & -0.7 & -0.1 & 0.1 & 0.1 \\
\hline WTZR & 4075580.5563 & 931853.7992 & 4801568.1419 & -0.0160 & 0.0174 & 0.0096 & -0.4 & 0.7 & 0.1 & 0.1 \\
\hline
\end{tabular}


Table 3 (continued) ITRF2008 coordinates (epoch 2005.0), velocities and horizontal intraplate velocities of processed sites.

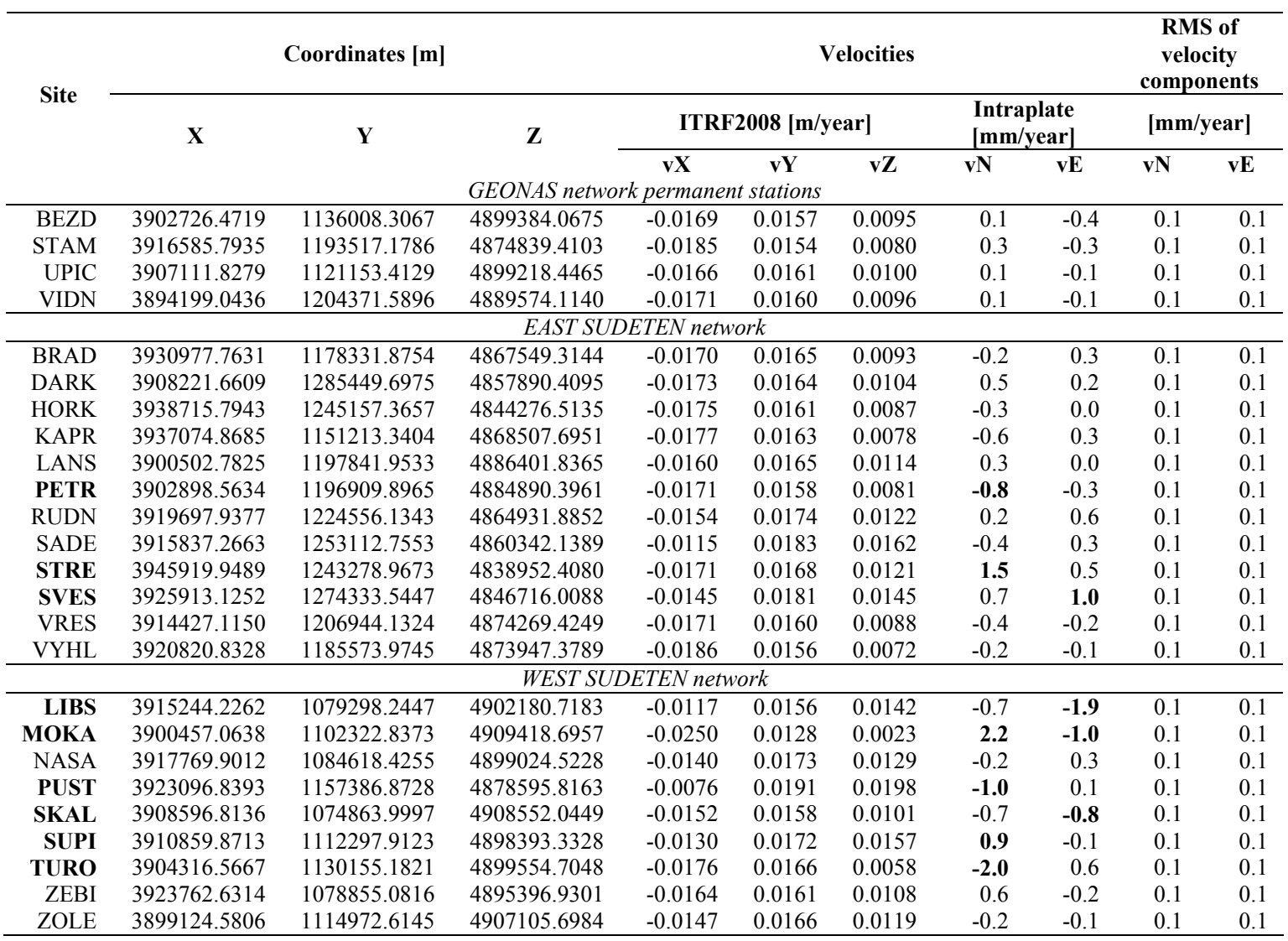

(Boucher and Altamimi, 2011). Results after the biases removal (dvN(red), $\mathrm{dvE}(\mathrm{red}))$ are also presented in Figure 6. The comparisons (Figures 4 and 6) show for the permanent stations, the average agreement of obtained velocities with the reference data on the level of $0.3 \mathrm{~mm} /$ year. Comparison of velocities for epoch-observed sites cannot be done here, because no velocity results expressed in ITRF2008 or ETRF2000(R08) were published for them.

Following the conclusions presented by Altamimi et al. (2012), the weighted RMS error of ITRF2008 plate-motion model is $0.3 \mathrm{~mm} /$ year $\left(\sigma_{\text {ITRF 2008-PMM }}\right)$. The estimated accuracies of horizontal velocity components (Table 3) and the ITRF2008 plate-motion model weighted RMS error should be taken into account during the geodynamic interpretations. The significant intraplate velocities should exceed their $95 \%$ confidence level error ellipses. Because the North and East RMS error components $\left(\sigma_{N E}\right)$ of intraplate velocities (Table 3) are equal to $0.1 \mathrm{~mm} /$ year, ellipses are circular and their radius $\left(r_{95 \%}\right)$ for $95 \%$ confidence level may be calculated as: $r_{95 \%}=2.45 * \sqrt{\sigma_{N E}^{2}+\sigma_{I T R F 2008-P M M}^{2}}=0.8 \mathrm{~mm} /$ year,

where 2.45 is the scaling factor, computed as the square root of $X_{(f=2.1-\alpha=95 \%)}^{2}=5.99$ using the assumption that North and East velocity components are independent, and have normal distributions.

The comparison of horizontal velocity vector components (Table 3) with the $r_{95 \%}$ value shows, that $25 \%$ of all sites have significant values of velocities. These sites were marked bold in Table 3 . Geodynamic interpretation of detected significant velocities will be the matter of future works.

Hefty et al. (2010) mentioned, that geodynamic interpretation of the velocity pattern strongly depends on the model applied for reducing the Eurasia platemotion and the selection of fiducial sites used for referencing. As evident, it is a serious problem to compare the recent results with those obtained previously. In calculations of the previous results, the ITRF2008 or ETRF2000(R08) were not used and also the same fiducial sites were not always applied. Therefore, the interpretations of the recent site velocity pattern should be in future firstly done selectively from local and regional views with taking into account the aspects already found. 


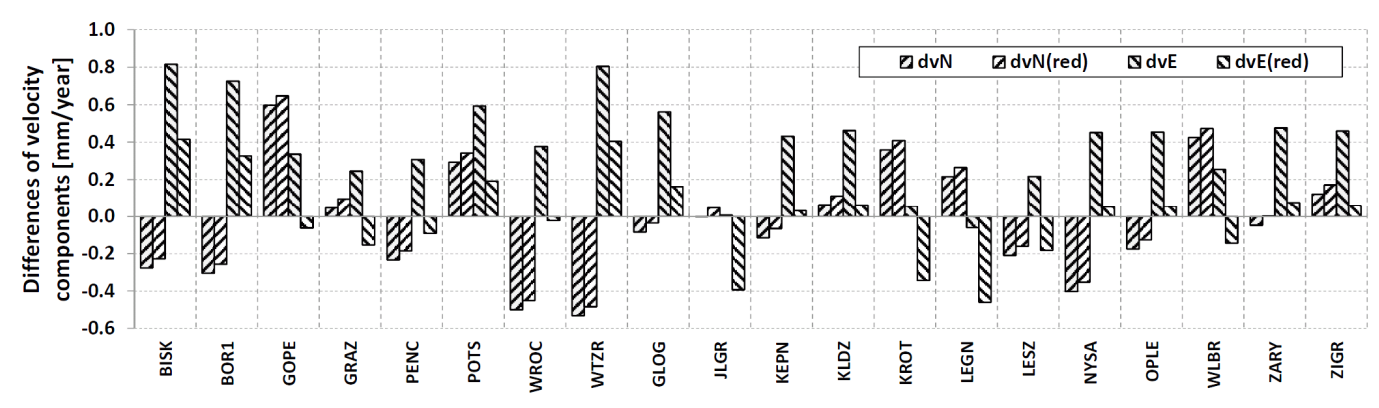

Fig. 6 Differences of horizontal intraplate velocities (ITRF2008 reduced with ITRF2008 plate model) and ETRF2000(R08) velocities of EPN class A and ASG-EUPOS stations.

\section{CONCLUSIONS}

Presented intraplate velocities were evaluated by means of the ITRF2008 model for the area of the research. They represent a complex reprocessing of all GPS data observed during 1997-2012 period on the geodynamic networks GEOSUD, EAST and WEST SUDETEN situated in the Czech and Polish territories. Applied solution gave a reasonable evaluation of site velocity pattern. The site velocities reflect complexity of geological structures of this area, where individual Sudetic and Moravo-Silesian blocks of the Bohemian Massif are affected by active dynamics of the West Carpathians and Alpine orogene structures.

\section{ACKNOWLEDGEMENTS}

The joint activity of the Polish and the Czech researches could not be realized without considerable supports of many national institutions: the Grant Agency of the Czech Republic (Projects 205/97/0679 and 205/01/0480), the Grant Agency of the Academy of Sciences of the Czech Republic (Project IAA300460507), the Ministry of Education, Youth and Sports of the Czech Republic (Projects LN 00A005, LC 506, 1P05ME781 and LM 2010008) and the State Committee for Scientific Research in Poland (Projects 9T12E 00510 and 9T12E02918).

Substantive support for GEOSUD/SUDETEN GPS data reprocessing was gained from the Polish National Science Centre (grant No. N526 278940). The authors thank to Dr. Karolina Szafranek and Prof. Mariusz Figurski from the Military University of Technology in Warsaw for the results of cumulative ASG-EUPOS solution. The authors wish to extend their sincere thanks to all persons who participated in annual GPS campaigns or helped with their realisation.

\section{REFERENCES}

Altamimi, Z., Collilieux, X., Legrand, J., Garayt, B. and Boucher, C.: 2007, ITRF2005: A new release of the International Terrestrial Reference Frame based on time series of station positions and Earth Orientation
Parameters, Journal of Geophysical Research, 112, B09401. DOI: 10.1029/2007JB004949.

Altamimi, Z., Métivier, L. and Collilieux, X.: 2012, ITRF2008 plate-motion model. Journal of Geophysical Research, 117, B07402. DOI:10.1029/2011JB008930

Bosy, J., Figurski, M. and Wielgosz, P.: 2003 A strategy for GPS data processing in a precise local network during high solar activity. GPS Solutions, 7, No. 2, Berlin Heidelberg - New York. 120-129. DOI: 10.1007/s10291-003-0052-8

Bosy, J. and Kontny, B.: 1998, Strategy of GPS data processing in local geodynamical networks. Reports on Geodesy, No. 9 (39), Warsaw University of Technology, Institute of Geodesy and Geodetic Astronomy, 105-114.

Bosy, J., Kontny, B. and Cacoń, S.: 2006, The Earth crust surface movements in SW Poland from GPS and leveling data. Reports on Geodesy, No. 1(76). Warsaw University of Technology, Institute of Geodesy and Geodetic Astronomy, 301-311.

Boucher, C. and Altamimi, Z.: 2011, Memo: Specifications for reference frame fixing in the analysis of a EUREF GPS campaign, http://etrs89.ensg.ign.fr/memo-V8.pdf

Brockmann, E.: 1996, Combination of solutions for geodetic and geodynamic applications of the Global Positioning System. Geodätisch-geophysikalische Arbeiten in der Schweiz, Schweizerischen Geodätischen Kommission, Vol. 55.

Cacoń, S., Bosy, J. and Kontny, B.: 1999, The GPS levelling network in the conurbation of Wrocław. Artificial Satellites, Journal of Planetary Geodesy, 34, No. 3, $163-170$.

Cacoń, S. and Dyjor, S.: 1999, Neotectonic and recent movements of the Earth crust in Polish part of the Sudeten and the Fore-Sudetic Block. International Journal of Exploration Geophysics, Remote Sensing and Environment, VI, No. 2, 11-16.

Cacoń, S., Kontny, B. and Bosy, J.: 1998, Recent geodynamics of Eastern Sudety Mountains and Foreland. Reports on Geodesy No. 9(39), Warsaw University of Technology, Institute of Geodesy and Geodetic Astronomy, 115-124.

Dach, R., Hugentobler, U., Fridez, S. and Meindl, M. (eds.): 2007, Bernese GPS software version 5.0. Astronomical Institute, University of Bern.

Grzempowski, P., Badura, J., Cacoń, S., Kapłon, J., Rohm, W. and Przybylski, B.: 2012, Geodynamics of South- 
Eastern part of the Central European Subsidence Zone. Acta Geodyn. Geomater., 9, No. 3 (167), 359369.

Hefty, J., Hipmanová, L., Gerhátová, L., Igondová, M. and Drošćák, B.: 2010, recent geo-kinematics of Slovakia based on homogenized solutions of permanent and epoch GPS networks. Acta Geodyn. Geomater., 7, No. 3 (159), 303-315.

Hugentobler, U., Schaer, S. and Fridez, P.: 2001, Bernese GPS software - version 4.2. Astronomical Institute, University of Bern, pp. 515 .

Kapłon, J. and Cacoń, S.: 2009, Research on the Marginal Sudetic Fault activity with use of GPS and precise leveling techniques. Acta Geodyn. Geomater., 6, 3 (155), 323-329.

Kontny, B.: 2003, Geodetic research of contemporary kinematics of the main tectonic structures of the Polish Sudetes and the Fore-Sudetic Block with the use of GPS measurements (in Polish with English summary). Zeszyty Naukowe AR we Wrocławiu, 468, Rozprawy, CCII, 146 pp.

Schenk, V., Cacoń, S., Bosy, J., Kontny, B., Kottnauer, P. and Schenková, Z.: 2002, The GPS geodynamic network SUDETEN - Five annual campaigns (19972001). Data processing and results. Acta Montana, Ser. A, No. 20(124), 12-23.

Schenk, V., Cacoń, S., Schenková, Z., Kontny, B., Bosy, B. and Kottnauer, P.: 1999, GPS Regional geodynamic network SUDETEN, EGRS - The International Journal of Exploration Geophysics, Remote Sensing and Environment, VI , No. 2, 28-30.

Schenk, V., Kaláb, Z. and Grygar, R.: 2000, Mobility of tectonic zones in the northern part of the MoravoSilesian region and their earthquake activity. Acta Montana, ser. AB, No. 8(115), 47-60.
Schenk, V., Kaláb, Z. Grygar, R., Holub, K., Jelínek, J., Knejzlík, J., Kottnauer, P. and Schenková, Z.: 2004a, Fundamental mobility trends in the northern part of the Moravo-Silesian zone (the Bohemian Massif) - A complex geodynamic analysis, Acta Research Reports, No. 13, 75-90.

Schenk, V., Kottnauer, P., Schenková, Z. and Hájek, P.: 2004b, Czech permanent GPS observatories for geodynamic investigations of the Bohemian Massif operated by the Institute of Rock Structure and Mechanics, Prague. Acta Geodyn. Geomater., 1, No. 3(135), 111-114.

Schenk, V., Schenková, Z., Bosy, J. and Kontny, B.: 2010a, Reliability of GPS data for geodynamic studies. Case study: Sudeten area, the Bohemian Massif. Acta Geodyn. Geomater. , 7, No. 1(157), 113-128.

Schenk, V., Schenková, Z., Cacoń, S., Kontny, B., Bosy, J. and Kottnauer, P.: 2003, To geodynamic interpretations of GPS data monitored on the East Sudeten network. Acta Montana, Ser. A, No. 24(131), 87-97.

Schenk, V., Schenková, Z., Cajthamlová, M. and Fučík, Z.: 2010b, GEONAS - Geodynamic network of permanent GNSS stations within the Czech Republic. Acta Geodyn. Geomater., 7, No. 1(157), 99-111.

Schenk, V., Schenková, Z., Grácová, M. and Kottnauer, P.: 2006, Preliminary site movements in the GPS WEST SUDETEN network.. Acta Geodyn. Geomater., 3, No. 3(143), 45-51. 